\title{
Sustainable Social SPENDING IN A GREYING ECONOMY WITH STAGNANT PUBLIC SERVICES: BAUMOL’s Cost DisEASE REVISITED
}

\author{
FREDERICK VAN DER PLOEG \\ CESIFO WORKING PAPER NO. 1822 \\ CATEgory 1: Public FinANCE \\ OCTOBER 2006
}

An electronic version of the paper may be downloaded

- from the SSRN website:

- from the RePEc website:

www.SSRN.com

- from the CESifo website:

www.RePEc.org

www.CESifo-group.de 


\title{
SUSTAINABLE SOCIAL SPENDING IN A GREYING ECONOMY WITH STAGNANT PUBLIC SERVICES: BAUMOL’S COST DISEASE REVISITED
}

\begin{abstract}
Baumol's cost disease states that relatively high productivity growth in manufacturing induces a steady increase in the relative price of human services. If demand for these services is inelastic or manufactured goods are necessities, the budget share of these services inexorably rises over time and labour gradually shifts from manufacturing to services. If the care for children and elderly releases time for households, labour supply and the budget share of human services expand over time. This paper addresses the sustainability of human services such as care and education in a greying economy if they are financed by labour taxes. A productivity growth differential in favour of the market sector pushes up the tax rate and public sector employment if private goods and public services are poor substitutes, labour supply is relatively inelastic and there are not too many pensioners and children. Private affluence and public squalor result if labour supply is very elastic, the dependency ratio is large and the market provides good substitutes for public services. Greying of the population boosts demand for public employment if the market provides poor substitutes for public services, but the provision of public services per dependent may fall due to the erosion of the tax base. Subsequently, we discuss the situation where market and public employment are imperfect substitutes for households, the utility of money is not constant and public sector productivity depends on public sector pay.
\end{abstract}

JEL Code: E62, H0, J22, J31, J4, O40.

Keywords: Baumol's cost disease, Wagner's law, time price, congestion of public services, public squalor, private affluence, tax burden, cost of public funds, differential productivity growth, greying of population, public sector pay.

\author{
Frederick van der Ploeg \\ Robert Schuman Centre \\ European University Institute \\ Badia Fiesolana \\ Via dei Roccettini 9 \\ 50016 San Domenico di Fiesole (FI) \\ Italy \\ rick.vanderploeg@iue.it
}

September 2006 


\section{Introduction}

The sustainability of the welfare state is on top of the political agenda of many countries. Many reasons can be advanced varying from the growing pressures of increasing globalisation, the increase in the relative price of public services, greying of the population, slowing down of labour productivity growth and rising unemployment and dependency on the welfare state to the disincentive effects and moral hazard inherent in the tax and benefit systems comprising the modern welfare state (e.g., Lindbeck, 2005). Here we explore the implications of a greying population on the tax burden and provision of public services, but focus primarily on the increase in the relative price of public services caused by the productivity growth in care of the elderly, child care, education and other human services falling short of the productivity growth in the market sector (Baumol, 1967; Baumol, Blackman and Wolff, 1985). Nurses and teachers are needed to take care of the elderly and children, but cannot be replaced by machines. Consequently, there is less scope for productivity growth in these public services than in the market sector and relative prices of such human services must increase steadily over time. Recent empirical evidence for US data for the period 1948-2001 suggests that stagnant industries indeed show a higher growth in relative prices (Nordhaus, 2006). ${ }^{1}$ In fact, the higher growth in relative prices is almost exactly equal to the productivity growth differential. Although these findings are based on value added rather than output data and fraught with measurement problems especially in sectors like health, education and personal services where the output measures are really measures of input, they support Baumol's main hypothesis. The same study also suggests that industries with a one-percentage-point lower productivity growth are associated with threequarters percentage-point lower growth in real output. The reason is that the higher relative prices implied by the cost disease depress demand for those industries. Interestingly, wages and profits are mainly determined by the aggregate economy rather than productivity experiences of individual sectors. Because the composition of output has shifted away from industries with rapid productivity growth like manufacturing to those with stagnant technologies like government, education and construction, Nordhaus concludes that aggregative productivity growth in the US has slowed down by more than one-half percentage-point over the last half century.

We want to provide more insight into Baumol's cost disease and investigate some public finance implications of stagnant human services being financed out of the public purse. It is important to examine under which conditions the budget share of the stagnant sectors in

\footnotetext{
${ }^{1}$ Similarly, for the Netherlands the annual percentage growth rate in costs per unit of output of the education, care and police/justice were, respectively, 1.9, 1.1 and 4.5 percentage points above that in the market economy during 1990-2000 (Kuhry and van der Torre, 2002). The annual growth rate of the total of these public services was 1.6 percentage points higher than in the market economy.
} 
total income increases over time. With Cobb-Douglas preferences the budget share of human services and other stagnant sectors will be constant over time. However, this budget share steadily increases over time if human services and other economic products and services are poor substitutes. Also, if human services are luxuries, Wagner's law kicks in and the budget share of human services increases over time. Human services such as care for children and the elderly release time for work and leisure. In that case, the time cost of human services falls less than the relative price of human services, and thus the national income share of human services and labour supply increase over time. It may be more consistent to reserve the term Baumol's cost 'disease' for the case where the budget share of human services increases over time. Following the literature, the term 'disease' is used but no normative implications are intended. In fact, as people grow wealthier due to technological advances, they are well able to afford the ever more expensive human services.

One way to avoid the cost disease is to allow the gap between wages in the public sector and market sector to steadily increase over time or to let the quality of human services deteriorate. Of course, it then becomes increasingly difficult to recruit, retain and motivate people to work in public services. Clearly, this solution to the cost disease will not be feasible in the long run. Although nurses and teachers are dedicated professionals and may be prepared to work for a relatively low wage, this cannot explain an ever-increasing wage gap. There is also no empirical evidence for such an ever-increasing gap (e.g., Nordhaus, 2006).

To make sure that demand and provision of these crucial public services do not fall, it is often argued that government subsidy is required. This is not really a very convincing argument, since the persistent increases in productivity in the market sector give rise to steady increases in purchasing power. If people value human services, they will use their new riches to pay for it. Since these services typically have income elasticities greater than unity, the provision of these services may flourish as technical progress makes people wealthier. In particular, if demand for public services is inelastic, suppliers of these services can raise prices and revenues sufficiently to compensate for rising costs. Furthermore, Baumol's cost disease may set in motion offsetting trends. The rise in the relative price causes a shift towards less labour-intensive public services such as robots for the care of the elderly or the use of video and Internet in teaching. Technology may thus induce new economies of scale and substitution in consumption. In addition, both the increased use of the Internet and the fall in transport costs induce a shift from small-scale to large-scale providers of public services. Still, the bulk of human services are in nursing, childcare and education. In those sectors the scope for productivity improvements is limited unless one sacrifices quality. There is then a danger that free and equal access of public services is contested as high-income people increasingly opt out of public services and make use of private supplements. Obviously, this raises distributional issues. It also threatens the quality of public services if the best teachers and medical specialists 
are drawn into the private sector. If mixing pupils of different abilities and backgrounds is important for the overall quality of education, opting out also has detrimental effects.

Although there is a perception among politicians that more growth eases the financial problems of the welfare state, some argue that growth threatens the viability of tax-financed public services (e.g., Anderson, 2006). They argue that growth pushes expenditures on public services in the upward direction as people demand more and better public services (Wagner's law). Also, public services inherently have fewer possibilities for productivity growth and thus their cost will inexorably rise (Baumol's law). In addition, the tax base may be eroded as people develop a taste for working less (holidays, early retirement, shorter working hours), especially as many countries have during the last few decades already witnessed big increases in labour force participation. There are also limits to the acceptability of raising tax rates as distortions increase more than proportional with hikes in the tax rate. It is not clear that tax revenues can rise indefinitely, necessary to finance the growing demand for ever more expensive public services. The key question is, however, whether growth driven by technical progress really threatens the provision of tax-financed public services.

The objective of this paper is to investigate this 'growth puzzle' formally within a public finance framework and to examine whether rapid technical progress in the market sector really threatens the viability of the welfare state. Is it possible to avoid a future of public squalor and private affluence? Does growth lead to a decline in tax-financed public services? What happens to the tax rate and the cost of public funds as the relative price of public services inexorably rises over time?

Section 2 sets the scene and shows that in a two-sector market economy more rapid technological progress in manufacturing pushes up the relative price of human services and that the budget share of public services rises over time if manufactured goods are necessities or human services are luxury goods, manufactured goods and human services are poor substitutes, and human services such as care for children and the elderly release time for work or leisure. Sections 3 and 4 extend the basic analysis by investigating the impact of rapid technical progress in the market economy on provision of tax-financed public services with less scope for productivity improvements. They also explore the implications of greying of the population for the tax burden, the cost of public funds and the provision of public services. The analysis allows for the adverse effects of higher taxes on labour supply and also for congestion in the provision of public services. Section 3 abstracts from income effects in labour supply and obtains more clear-cut results. Section 4 demonstrates that it is important to allow for a variable wage elasticity of labour supply, so that as people work more hours it becomes increasingly difficult to entice them to work even more hours by granting a higher wage. Section 4 also allows for the negative impact of a greying population on labour supply. It concludes with some illustrative calculations in order to get an idea of the order of magnitudes. Section 5 allows for the 
immaterial joy of working in public services and investigates the consequences of imperfect substitution between public and private employment. This section also studies what happens to the provision of public services if nurses and teachers are poorly paid and thus supply less labour and become less productive. Section 6 concludes with a summary of the results and suggestions for further research.

\section{Baumol's cost disease: human services and manufacturing}

We first consider a market economy with a human services sector and a manufacturing sector. Human services include health care (not cure), education, legal services, car repair, restaurants, etc. Suppose services $\mathrm{S}$ has a relatively low growth rate in labour productivity $\rho_{S}$ and the market sector $\mathrm{M}$ has a higher growth rate in labour productivity $\rho_{M}>\rho_{S}$. Following Baumol (1976) we refer to services as the stagnant sector and manufacturing as the progressive sector:

"The common element that characterizes all stagnant services is the handicraft attribute of their supply process. None of them has, at least so far, been fully automated and liberated from the requirement of a substantial residue of personal attention by their producers. That is, they have resisted reduction in the amount of labor expended per unit of output."

Since services (in contrast to manufacturing) do not lend themselves for standardisation and quality is directly related to the labour used in production, human services do not enjoy rapid and persistent productivity growth. Output levels are $Y_{S}=\mathrm{A}_{S 0} L_{S} \exp \left(\rho_{S} \mathrm{t}\right)$ and $Y_{M}=\mathrm{A}_{\mathrm{M} 0} L_{M} \exp \left(\rho_{M} \mathrm{t}\right)$, where $L$ denotes employment, $\mathrm{t}$ indicates time and $\mathrm{A}_{\mathrm{S} 0}$ and $\mathrm{A}_{\mathrm{M} 0}$ are constants. We abstract from other factors of production. ${ }^{2}$ With labour mobility between services and manufacturing, wages in services must equal those in manufacturing. Hence, wages in services grow at the same rate as in manufacturing, namely at the rate of labour productivity growth, so that $W=\operatorname{Kexp}\left(\rho_{M} \mathrm{t}\right)$ where $\mathrm{K}$ is a constant. In fact, all we need is that wages in human services maintain their relative position, so they can be below wages in manufacturing. Unit labour costs in services rise at the labour productivity growth differential of manufacturing over services, but are constant in manufacturing:

$$
W L_{S} / Y_{S}=\mathrm{K} \exp \left[\left(\rho_{M}-\rho_{S}\right] \mathrm{t}\right] / \mathrm{A}_{\mathrm{SO}} \quad \text { and } \quad W L_{M} / Y_{M}=K / \mathrm{A}_{\mathrm{M}}
$$

If prices are a constant mark-up on unit labour costs, the price of services $P_{S}$ grows over time at the rate $\rho_{M}-\rho_{S}>0$ while the price of manufacturing $P_{M}$ stays constant. Of course, there is no guilty party for the persistent increase in the real price of services. Greed or waste play no role. 
With Cobb-Douglas preferences the budget shares of services and manufacturing are constant, so that the allocation of labour across the sectors $P_{S} Y_{S} / P_{M} Y_{M}=L_{S} / L_{M}$ is constant as well. If total labour demand $L_{S}+L_{M}$ equals exogenous labour supply, $L_{S}$ and $L_{M}$ are constant. It follows that output of services grows at the rate $\rho_{S}$ and manufacturing output at the rate $\rho_{M}$. Although the ratio of output of services to that of manufacturing output dwindles away and prices of services rise at the rate $\rho_{M}-\rho_{S}>0$, employment in services remains constant. Hence, Baumol's cost disease does not destroy jobs or output of services. The technological progress in manufacturing boosts purchasing power of people sufficiently to keep up expenditures on services despite rising prices of services. Also, the cost of human services in terms of the hours one needs to work to afford them falls at the rate $\rho_{S}$. The hours work needed to buy a unit of manufacturing output falls at a higher rate, namely $\rho_{M}$. As a result, the real consumption wage grows at the rate $\alpha \rho_{M}+(1-\alpha) \rho_{S}$, where $0<\alpha<1$ indicates the budget share of manufacturing, even though that the consumer price index grows at the rate $(1-\alpha)\left(\rho_{M}-\rho_{S}\right)>0$. In the public debate the steady growth in the price of human services is often confused with a steady growth in the real cost of human services. Clearly, that is not right as the real cost of human services is at worst constant and more likely will fall at a modest rate each year.

\subsection{Wagner's law}

One shortcoming of the above discussion of Baumol's cost disease is that Cobb-Douglas preferences and any other form of homothetic preferences imply linear Engel curves and unit income elasticities of demand for services and manufacturing. However, manufactured goods may be necessities and include basic needs such as food, drink, clothing and shelter while services such as care and education often are luxury goods. Indeed, Wagner's law suggests that human services have an income elasticity greater than one. In that case, non-homothetic preferences are more appropriate. The budget share of services then rises over time, since people assign relatively more priority to basic needs if they are poor and more to luxury services as they grow richer. To illustrate this more formally, consider the Stone-Geary utility function $U=\alpha \log \left(Y_{M}-Y_{M^{*}}\right)+(1-\alpha) \log \left(Y_{S}\right)$, where $0<\alpha<1$ and $Y_{M^{*}}>0$ is the constant subsistence level of manufactured goods. The household budget constraint is $P_{M} Y_{M}+P_{S} Y_{S}=Y$, where income $Y$ grows at the rate $\rho_{M}$. If manufacturing is the numéraire with $P_{M}=1$ and $P_{S}=P$, the optimal budget shares of services (which equals the fraction of labour employed in human services) and the budget share of manufactured goods are given by, respectively:

$$
P Y_{S} / Y=L_{S} /\left(L_{S}+L_{M}\right)=(1-\alpha)\left(1-Y_{M} * / Y\right)<1-\alpha \text { and } Y_{M} / Y=\alpha+(1-\alpha) Y_{M} * / Y>\alpha
$$

\footnotetext{
${ }^{2}$ However, if there is also capital and the interest rate is determined on world capital markets, the capital intensities and thus the constants $\mathrm{A}_{\mathrm{M} 0}$ and $\mathrm{A}_{\mathrm{S} 0}$ are also pinned down by the world interest rate. $\mathrm{A}$
} 
Due to more rapid technical progress in manufacturing than in services, the budget share of services gradually rises over time as the demand for necessities is fulfilled. Since $P Y_{S} / Y_{M}=$ $L_{S} / L_{M}$ rises over time, labour moves from manufacturing to services.

\subsection{Enjoying human services takes time}

Human services take up time, which cannot be spent on leisure or work. Enjoying Wagner's Ring requires many hours in the opera. Investing in one's own education also requires many hours of hard studying. Suppose therefore that it takes $\gamma$ units of time to consume human services and assume that labour supply is endogenous. Take for simplicity a Cobb-Douglas utility function $\mathrm{U}\left(Y_{M}, Y_{S}, V\right)$, where leisure is given by $V=1-L-\gamma S$ and $L$ indicates labour supply. ${ }^{3}$ Maximising utility subject to the budget constraint $Y_{M}+P Y_{S}=W L$ yields the budget share of human services, relative budget (and employment) share and labour supply:

(3) $\frac{P S}{W L}=\frac{\beta P /(P+\gamma W)}{\alpha+\beta P /(P+\gamma W)}, \frac{P S}{C}\left(=\frac{L_{S}}{L_{M}}\right)=\frac{\beta P}{\alpha(P+\gamma W)}$ and $L=\alpha+\beta\left(\frac{P}{P+\gamma W}\right)$,

where $P+\gamma W$ denote the 'time price' of human services. If productivity growth in human services is positive but less than in manufacturing, the cost of human services rises less fast than wages, the growth in the 'time price' of human services exceeds the growth in the market price of human services. Consequently the budget share of human services in wage income falls over time and that of manufactured goods falls. Labour supply falls over time as more time is needed to consume human services. In equilibrium total labour supply must match total labour demand, so employment in manufacturing and human services are given by:

$$
L_{M}=\alpha \text { and } L_{S}=\beta P /(P+\gamma W) \Rightarrow \hat{L}_{M}=0 \text { and } \hat{L}_{S}=-\left(\frac{\gamma W}{P+\gamma W}\right) \rho_{S} \leq 0 \text {, }
$$

where we used that the growth rate in $W / P$ equals $\rho_{S}$. We thus conclude that employment in manufacturing employment is unaffected by relatively rapid technical progress in manufacturing, whereas employment in human services gradually declines over time if $\gamma>0$.

Of course, other human services may free up time for leisure and work such as professional childcare or care of elderly parents. In that case, $\gamma<0$ and the results are reversed. In other words, with the passage of time, the national income share of care for children and 
pensioners increases and that of manufactured goods declines. The 'time cost' of these human services is relatively less strong than the relative price of human services. As a result, labour supply expands in order to satisfy the extra demand for labour in human services.

\subsection{Services and manufacturing are poor substitutes}

It is also relevant to extend the discussion of Baumol's cost disease to allow for an elasticity of substitution between services and manufacturing that is less than unity, since manufactured goods are likely to be poor substitutes for care or education. A CES utility function with an elasticity of substitution less than unity generates a budget share of public services that rises over time. For example, the homothetic utility function $\mathrm{U}\left(Y_{M}, Y_{S}\right)$ yields the first-order optimality condition $\mathrm{U}_{\mathrm{S}} / \mathrm{U}_{\mathrm{M}}=P$. Loglinearisation gives $Y_{M}-Y_{S}=\theta P$, where $\theta>0$ is the elasticity of substitution between manufactured goods and services. Together with $\hat{P}=\rho_{M}-\rho_{S}$ and the budget constraint, $\phi Y_{M}+(1-\phi)\left(P+Y_{S}\right)=Y$ where $0<\phi \equiv Y_{M} / Y<1$, we obtain:

$$
\begin{gathered}
Y_{M} / Y=-(1-\theta)(1-\phi)\left(\rho_{M}-\rho_{S}\right)<0, P Y_{S} / Y=(1-\theta) \phi\left(\rho_{M}-\rho_{S}\right)>0 \\
\quad \text { and } \hat{L}_{S}-\hat{L}_{M}=(1-\theta)\left(\rho_{M}-\rho_{S}\right)>0 \text { if } \theta<1 .
\end{gathered}
$$

We thus see that as long as manufactured goods and services are poor substitutes $(\theta<1)$ and manufacturing has a relatively high productivity growth rate $\left(\rho_{M}>\rho_{S}\right)$, the budget share of manufactured goods declines over time and that of services rises over time. Again, workers gradually move from manufacturing towards services.

\subsection{Summing up}

Our results can be summarised by the following proposition.

Proposition 1: In a two-sector market economy, the relative price of human services increases at the excess of the rate of productivity growth in manufacturing over that in services. With Cobb-Douglas preferences the allocation of employment across the two sectors remains constant. However, the budget share of services and the fraction of the labour force employed in services rise over time if services are luxury goods or poor substitutes for manufactured goods. If human services replace household services and release time for work and leisure, the national income share of human services and the level of employment in human services increase over time as well.

\footnotetext{
${ }^{3}$ A more general analysis requires disentangling income and substitution effects (e.g., Baumol, 1973).
} 
Hence, despite rising relative prices of human services, there are good reasons to believe that the budget share and employment share of human services gradually increase over time. People become sufficiently rich due to technological advances to be able to afford that and welfare benefits from more rapid technical progress in manufacturing. Furthermore, the stagnant sectors may not be that stagnant after all and there may be a shift towards less labour-intensive human services which are due to the Internet and falling labour costs supplied on a much larger scale. Indeed, Cowen (1996) in response to Baumol (1996) and Triplett and Bosworth (2003) argue that Baumol's cost disease has been cured. It is thus curious that the phenomenon of a rise in the relative price of human services has become known as a 'disease'. In fact, the term 'disease' has been used with some success by lobbies in care, education and the arts to obtain more government subsidies. They rightly argue that these public services suffer from ever-increasing costs and thus that they should be compensated by the government. If the government has access to non-distorting taxes, there is no problem with giving in to these lobbies as rapid technical progress in the market sectors is making the country wealthier all the time. However, the rationale for growing subsidies is less clear if they are to be financed by distorting taxes. The term 'disease' may then refer to the potential adverse incentive effects on labour supply and saving of a growing demand for taxation. This way of looking at Baumol's cost disease clearly is of utmost policy relevance. The key question is whether Baumol's cost disease inevitably leads to a situation of public squalor and private affluence. In the next sections we thus modify the basic framework of Baumol's cost disease to allow for a public finance setting, where services are the responsibility of the government and financed by taxes on labour income.

\section{Public finance aspects of Baumol's cost disease}

We investigate the implications of Baumol's cost disease for labour supply and the tax burden within the context of a two-sector model of the economy. Sector $\mathrm{M}$ is the market and sector $\mathrm{P}$ the public sector. We abstract from saving and investment. We thus address the sustainability of social spending and the welfare state in the light of (i) stagnant public services and rapid technological advances in manufacturing, and, (ii) a rise in the dependency ratio arising from, say, greying of the population.

To simplify matters and set the scene for the next section, we briefly consider the case of a constant marginal utility of private consumption, abstract from income effects in labour supply, and assume that households consider market and public employment perfect substitutes. We also focus on the provision of public services and thus abstract from a public pension system for dependants; households simply take of their own pensions. The main effect of greying we now highlight is on the rise in the demand for public services especially if they are rival goods. Households therefore maximise the utility function 
$U=C-\left(\frac{\varepsilon}{1+\varepsilon}\right)\left(L_{M}+L_{P}\right)^{\frac{1+\varepsilon}{\varepsilon}}$ subject to the budget constraint $C=(1-T)\left(W_{M} L_{M}+W_{P} L_{P}\right)$ where $C, L_{M}, L_{P}, W_{M}$ and $W_{P}$ indicate private consumption (including that of dependants), market employment, public sector employment, the market wage and the public sector wage, respectively. This yields the labour supply schedule $L \equiv L_{M}+L_{P}=\left[(1-T) W_{M}\right]^{\varepsilon}$ with $\varepsilon \geq 0$ the constant Frisch wage elasticity of labour supply. Labour mobility ensures that pay in the public sector matches that in the market economy, i.e., $W_{M}=W_{P}=A_{M}$ where $A_{M}$ stands for the productivity of market employment. The provision of public services per dependant is given by $S \equiv A_{P} L_{P} / D^{v}$, where $A_{P}$ denotes public sector productivity and $D$ denotes the number of dependants in the economy. If public services are rival goods, more public sector employment is needed to take care of a larger group of dependants and thus $v=1$. If public services are nonrival goods, $v=0$. In general, $v$ indicates the degree of rivalry of public services. The optimal tax rate $T$ and provision of public services per dependant $S$ follow from the following optimisation problem for the government:

(6) $\operatorname{Max}_{T, L_{P}} \Omega=\left(\frac{1}{1+\varepsilon}\right)\left[(1-T) A_{M}\right]^{1+\varepsilon}+\mathrm{V}\left(A_{P} L_{P} / D^{\nu}\right)$ subject to $L_{P}=T\left[(1-T) A_{M}\right]^{\varepsilon}$

where the first term stands for indirect private utility and the second term $\mathrm{V}(S), \mathrm{V}^{\prime}>0, \mathrm{~V}^{\prime \prime}<0$ captures the value of public services in social welfare $\Omega$. The marginal value of the provision of public services should equal its cost times the marginal cost of public funds $\eta$ :

$$
\mathrm{V}^{\prime}(S)=P D^{v} \eta \text { with } \eta \equiv \frac{1}{1-\varepsilon\left(\frac{T}{1-T}\right)} \geq 1, \quad P=\frac{A_{M}}{A_{P}} \text { and } S=\frac{A_{P} L_{P}}{D^{v}}
$$

If public services are non-rival the cost is simply the price $P$, but if public services are rival the cost corresponds to the price times the number of dependants, i.e., $P D$. In general, congestion effects in public services $(v>0)$ imply that a higher number of dependants requires a higher level of public sector employment to maintain the same quality of public services and thus pushes up the cost of public services. The cost of public funds is large if the wage elasticity of labour supply $\varepsilon$ and the tax rate on labour are large. If labour supply is inelastic, taxes are not distorting, the cost of public funds is fixed at unity and thus (7) reduces to the Samuelson rule $\mathrm{V}^{\prime}(S)=P D^{v}$. In general, given that the wage elasticity of labour supply $\varepsilon$ is constant, the cost of public funds simply increases with the tax rate (provided $\varepsilon>0$ and $\eta>1$ ): 


$$
\hat{\eta}=\left(\frac{\eta-1}{T}\right) \hat{T}
$$

where a hat indicates a relative change (e.g., $\hat{\eta} \equiv d \eta / \eta$ except for $\hat{T} \equiv d T /(1-T)$ ). With the aid of (8), we loglinearise (7) and obtain the change in the demand for public services:

$$
\begin{aligned}
& E_{P}=(1-\psi)\left(v D-\AA_{P}\right)-\psi\left[\AA_{M}+\left(\frac{\eta-1}{T}\right) \hat{T}\right] \text { and } \\
& \hat{S}=-\psi\left[v \boxminus+\hat{P}+\left(\frac{\eta-1}{T}\right) \hat{T}\right], \quad \text { where } \psi \equiv-\mathrm{V}^{\prime} / S \mathrm{~V}^{\prime \prime} \geq 0
\end{aligned}
$$

The provision of public services per dependent $S$ thus decreases if the cost of funds, the relative price of public services or the number of dependants increases. Public employment also decreases if the cost of funds or the productivity in the market sector rises. Furthermore, provided the output effect dominates the substitution effect (i.e., $\psi<1$ ), greying of the population or a fall in public sector productivity boosts public employment.

To complete the comparative statics of the optimal provision of public services, we use the labour supply curve to loglinearise the government budget constraint $L_{P}=T L$ :

$$
\mathrm{L}_{P}=\varepsilon \AA_{M}+\left(\frac{1-T}{T}-\varepsilon\right) \hat{T}=\varepsilon \AA_{M}+\left(\frac{1-T}{\eta T}\right) \hat{T}
$$

The interpretation is clear. A higher tax rate immediately leads to more revenues and permits more public spending. Part of the extra revenues is choked off by the disincentive effect on labour supply, especially if the wage elasticity of labour supply $\varepsilon$ and thus the cost of public funds $\eta$ are large. Furthermore, a higher productivity in the market sector boosts the wage and labour supply, expands the tax base and thus allows for more spending on public services (if $\varepsilon>0$ ). Greying of the population in this specification of labour supply does not affect the tax base and thus does not require spending cuts in public services.

We can solve for the optimal value of the tax rate and the provision of public services from the demand schedule (9) and the government budget constraint (10):

$$
\hat{T}=\left[(1-\psi)\left(v D-\AA_{P}\right)-(\psi+\varepsilon) \AA_{M}\right] / \Delta,
$$


(12)

$$
\begin{aligned}
& L_{P}=\Delta\left\{(1-\psi)\left(v D-\AA_{P}\right)-\psi\left[1-\varepsilon T\left(\frac{\eta}{1-T}\right)^{2}\right] A_{M}\right\} \text { and } \\
& \hat{S}=-\Delta \psi\left\{\left[1+\varepsilon T\left(\frac{\eta}{1-T}\right)^{2}\right]\left(v D-A_{P}\right)-\left[1-\varepsilon^{2} T\left(\frac{\eta}{1-T}\right)^{2}\right] A_{M}\right\}
\end{aligned}
$$

where $0<\Delta \equiv\left(\frac{1-T}{\eta T}\right) /\left[\psi\left(\frac{\eta-1}{T}\right)+\left(\frac{1-T}{\eta T}\right)\right]<1$. We now interpret the solution (11)-(12).

Providing a better quality of public services and, assuming that public services are to some extent rival public goods, $v>0$ ), greying of the population (i.e., lower $A_{P}$ or higher $D$ ) induce, under the assumption that the output effect dominates the substitution effect (i.e., $\psi<1$ ), an expansion of public sector employment. To balance the budget, this necessitates a higher tax rate. After-tax wages in both the public sector and market economy fall and thus labour supply falls, which drives up the cost of public funds. These effects are particularly strong if $\psi$ is small, the wage elasticity of labour supply $\varepsilon$ is small, and the initial tax rate is not too high already. In contrast, greying of the population and a better quality (i.e., lower productivity) of public services reduces the provision of public services per dependant, $S$, despite the increase in public sector employment.

Rapid technical progress in the market sector (i.e., higher $A_{M}$ ) unambiguously drives up wages and broadens the tax base. This permits cuts in the tax rate and the cost of public funds. In fact, due to the falling tax rate, after-tax wages rise faster than the rate of technical progress in the market economy. Consequently, labour supply and the tax base rise even more, especially if the wage elasticity of labour $\varepsilon$ is large, thus permitting a substantial fall in the tax rate or a boost to the level of public sector employment.

Rapid technical progress also means that it is attractive to substitute from public to private utility and thus public sector employment will fall, especially if $\psi$ is large. Some of this fall in public sector employment will be off-set by the increase in labour supply and tax revenues, especially if the pre-existing tax rate and the wage elasticity of labour supply (i.e., $T$ and $\varepsilon$ ) are large. Rapid productivity growth in the market economy cuts public sector employment only if the inequality $\varepsilon T[\eta /(1-T)]^{2}<1$ holds. Consensus estimates of $\varepsilon$ for males and females are, respectively, 0.1 and 0.5 . For example, if the wage elasticity of labour and the tax rate are as high as 0.5 and 0.4 , respectively, the left hand side equals 1.25 and thus the inequality is violated. Hence, public sector employment only falls as productivity growth in the market economy takes off if the wage elasticity of labour supply and the tax rate are not too large. However, if the wage elasticity of labour supply and the tax rate are large, it is a 
real possibility that rapid productivity growth in the market economy boosts public sector employment. The elasticity of labour supply on the extensive margin is rather larger than that on the intensive margin, which makes it even harder to rule out a boost to public employment.

\section{Proposition 2:}

(A) Greying of the population and a lower productivity of public services increase public sector employment and push up the tax rate and the cost of public funds provided that substitution possibilities between public services provision and private utility are small. Even so, the provision of public services per dependant will fall.

(B) Rapid technical progress in the market economy expands labour supply and the tax base and drives down the tax rate and the cost of funds. It also encourages substitution from public services provision towards material welfare and thus leads to a cut in public sector employment. However, if the tax rate is high and labour supply is fairly elastic, the expansion of labour supply may boost public sector employment. In that case, Baumol's cost disease does not lead to public squalor and does not threaten the viability of the welfare state.

The main impact of greying is on the demand for public services. However, an unsatisfactory feature of the above analysis is that labour supply does not fall as a consequence of greying of the population. To remedy this, we could have utility increasing in leisure rather than falling in hours worked. For example, if we use the utility function $U=C-\left(\frac{\varepsilon}{1+\varepsilon}\right)\left(L_{M}+L_{P}+D\right)^{\frac{1+\varepsilon}{\varepsilon}}$ where the time constraint is $L+D=1-V$ and $V$ indicates leisure, we obtain the labour supply schedule $L=\left[(1-T) W_{M}\right]^{\varepsilon}-D$. We still obtain the optimality condition (7), but the cost of public funds now increases as the ratio of dependants to workers (i.e., $D / L$ ) increases:

$$
\mathrm{V}^{\prime}(S)=P D^{\nu} \eta \text { with } \eta \equiv \frac{1}{1-\varepsilon\left(\frac{T}{1-T}\right)\left(\frac{L+D}{L}\right)} \geq 1 \text {. }
$$

Not surprisingly, greying of the population makes it harder to raise public funds and thus the cost of public funds rises and the demand for public services falls. To save space, we do not analyse this extension. In any case, section 4 allows for a negative impact of greying on labour supply and also relaxes the assumption of a constant marginal utility of consumption. 


\section{Sustainable social spending with variable elasticity of labour supply}

We thus extend the analysis of section 3 to allow for (i) a varying marginal utility of consumption and (ii) both income and substitution effects in labour supply, and (iii) explicitly take account of greying of the population (an increasing number of dependants) on the time available to potentially active households. This implies a variable elasticity of labour supply, so that labour supply is more elastic if people enjoy a lot of leisure and inelastic if people have hardly any spare time left. It also implies that greying of the population has an adverse effect on labour supply.

\subsection{Labour supply and demand for market goods}

The representative household consists of potentially active members who work or enjoy leisure and inactive members such as children and pensioners who depend on the active members for support. Total time available to all members of the representative household is one unit. Households face the utility function $\Omega(U, S)$, where $U=\mathrm{U}(C, V)$ indicates a homothetic sub-utility function in consumption of market goods $C$ and leisure $V$, and $S$ denotes again the provision of public services per dependant. Households maximise utility subject to the budget constraint $C=W(1-T) L$ and the time constraint $L+V=1-D$, where $L$ denotes labour supply, $W$ the market wage and $T$ the tax rate. Over time the hours available for work of leisure decreases as the fraction of dependants $D$ increases with greying of the population. Utility maximisation by households takes the provision of public services $S$ as exogenous and requires that the marginal rate of substitution between leisure and consumption equals the net wage, $\mathrm{U}_{V} / \mathrm{U}_{C}=(1-T) W$. The relative changes in labour supply, leisure and private consumption follow readily:

$$
\begin{array}{r}
\hat{L}=\varepsilon(\hat{W}-\hat{T})-\delta \hat{D}, \quad \hat{V}=-\varepsilon\left(\frac{L}{V}\right)(\hat{W}-\hat{T})-\delta \hat{D}, \quad \hat{C}=(1+\varepsilon)(\hat{W}-\hat{T})-\delta \hat{D} \\
\text { where } \varepsilon \equiv(\sigma-1)\left(\frac{V}{1-D}\right), \delta \equiv\left(\frac{D}{1-D}\right), \delta D=D \hat{\delta}
\end{array}
$$

and $\delta$ denotes the dependency ratio (i.e., the number of inactive people divided by the number of active people in the population). The uncompensated wage elasticity of labour supply $\varepsilon$ is only positive if the substitution effect exceeds the income effect, that is if the elasticity of substitution between consumption and leisure $\sigma$ exceeds one. The elasticity of labour supply is variable. Labour supply becomes inelastic as the number of hours households work approaches the maximum, so that a very high wage is needed to encourage them to work a bit more. Conversely, labour supply is most elastic if households work few hours. Labour supply, 
leisure and private consumption now diminish with greying of the population. The private part of utility also falls with greying of the population and increases with the after-tax wage:

$$
\hat{U}=\left(\frac{L}{1-D}\right)(\hat{W}-\hat{T})-\delta \hat{D}
$$

\subsection{Trend increase in the relative cost of public services}

Output in the market sector is produced by private employment $L_{M}$ with a linear technology and an exogenous productivity growth rate of $\rho_{M}>0$ and is sold for consumption to households:

$$
C=A_{M} L_{M} \quad \text { where } A_{M}=\mathrm{A}_{\mathrm{M} 0} \exp \left(\rho_{M} t\right) .
$$

Clearly, with this technology the market wage is given by $W=A_{M}$ and grows with time at the rate of exogenous productivity growth in the market sector. Output of public services $G$ results from public employment and productivity growth at the rate $0<\rho_{P}<\rho_{M}$ :

$$
G=A_{P} L_{P} \text { and } P G=W_{P} L_{P} \text { where } A_{P}=\mathrm{A}_{\mathrm{P} 0} \exp \left(\rho_{P} t\right)
$$

and $P$ indicates the relative price of public services. Since public employment and private employment are perfect substitutes in private utility, workers in both sectors are paid the same wage. It follows that the price of public services must rise at a rate equal to the excess of the rate of productivity growth in the private over that in the public sector:

$$
P=A_{M} / A_{P}=\left(\mathrm{A}_{\mathrm{M} 0} / \mathrm{A}_{\mathrm{P} 0}\right) \exp \left[\left(\rho_{M}-\rho_{P}\right) t\right] \text { as } W=P A_{P}=A_{M} .
$$

The delivery of social services such as health care and education is done by nurses and teachers and offers less scope for productivity growth than the production of market goods. With a stagnant public sector and fast-growing productivity in the market sector, prices of public services must inexorably rise, $P / P=\rho_{M}-\rho_{P}>0$. This is what has been coined Baumol's cost disease (Baumol, 1967; Baumol, Blackman and Wolff, 1985), but it remains to be seen whether it really has the features of a disease. The key question is whether this ongoing increase in the relative price of public services leads to an ever-increasing tax base and to a continuous fall in the demand for public services or not. To answer these questions, we turn to the government. 


\subsection{Demand for public services}

The government values the provision of public services per dependant. We thus assume that the government maximises the following social welfare function:

$$
\Omega(\mathrm{U}(C, V), S) \text { where } S=A_{P} L_{P} / D^{v}, \quad 0<v<1
$$

If public services are a rival good, $v=1$. If they are a non-rival good, $v=0$. With greying of the population and $v>0$, the government needs to supply more public services to prevent social welfare from falling. The government faces the constraint that public services must be financed by tax revenues, that is $P G=W L_{P}=T W L$. Labour market equilibrium requires that $L=L_{M}+L_{P}$. It follows that the government solves:

$$
\operatorname{Max}_{T, L_{P}} \Omega\left(\mathrm{U}^{*}\left((1-T) A_{M}, D\right), A_{P} L_{P} / D^{\nu}\right) \text { subject to } L_{P}=T L^{*}\left((1-T) A_{M}, D\right),
$$

where $L^{*}($.$) indicates the labour supply schedule and U^{*}($.) denotes the indirect private utility function defined by (13) and (14), respectively. This yields the condition for the optimal provision of public services:

$$
\frac{\Omega_{S}(U, S)}{\Omega_{U}(U, S)} \frac{C(1-D)}{L U}=P D^{v} \eta \text { with } \eta \equiv \frac{1}{1-\varepsilon\left(\frac{T}{1-T}\right)} \geq 1
$$

It says that the marginal rate of substitution between public services and private consumption must equal the relative cost of public services corrected for the dependency ratio, i.e., $P D^{v}$, times the marginal cost of public funds $\eta$. If public services suffer from congestion and are to a certain extent rival goods (e.g., nursing care, teaching), $\quad v>0$ and greying of the population raises the effective cost of providing human services. The cost of public funds captures the costs of distortions in labour supply, which are high if the wage elasticity of labour supply is large and the tax rate is large. Substituting the household budget constraint into the optimality condition (20) and loglinearising gives:

$$
\ddot{U}-\left(\hat{A}_{P}+\hat{L}_{P}-v \hat{D}\right)=\theta\left[\hat{P}+\hat{\eta}+\theta+\hat{T}-\hat{A}_{M}+(v+\delta) D\right]
$$

where $\theta$ is the elasticity of substitution between $U$ and $S$ in social welfare $\Omega$. Using (17) and substituting $U$ from (14) into (21) gives the demand for employment in public services: 
$(22)$

$$
\begin{aligned}
& \hat{L}_{P}=(1-\theta)\left[\left(\frac{L}{1-D}\right)\left(\hat{A}_{M}-\widehat{T}\right)-\hat{A}_{P}+v D\right]-\theta(\hat{\eta}+\hat{T})-\delta D \text { and } \\
& \hat{S}=(1-\theta)\left(\frac{L}{1-D}\right)\left(\hat{A}_{M}-\hat{T}\right)-\theta\left(\hat{\eta}+\hat{T}-\hat{A}_{P}\right)-(\delta+\theta v) D
\end{aligned}
$$

The final term on the right-hand side of (22) indicates that a greying population reduces labour supply and thus reduces public employment. The middle term states that demand for public services is less if the marginal cost of public funds is high, especially if substitution between public services and private utility is easy. The middle term also indicates that demand for public employment falls if the tax rate is high, because this implies a low after-tax wage (i.e., the opportunity cost of leisure) and a low level of private utility. Hence, it is optimal to substitute away from public services towards private utility. The first-term on the right-hand side of (22) indicates that, if private component of utility and public services are poor substitutes (i.e., $\theta<1$ ), technical progress in the market sector, productivity slowdown in public services and a lower tax rate boost the demand for employment in public services. To the extent that public services are rival goods, greying of the population then also boosts the demand for public employment. Conversely, the first term indicates that a higher price of public services driven by faster productivity growth in the market sector than in public services, a lower tax rate, lower productivity of public services and greying of the population depresses the public employment if the substitution effect dominates the income effect in social welfare (i.e., if $\theta>1$ ).

The net effect of greying of the population is to boost public employment if substitution possibilities between private utility and public services are small, public services are a rival good and the dependency ratio is not too high (i.e., if $(1-\theta) v>\delta$ ). Otherwise, greying reduces public employment. The net effect of greying on the provision of public services per dependant is negative even if public employment rises.

\subsection{The cost of public funds and the government budget constraint}

Although public services and private utility are likely to be poor substitutes, briefly consider the special case of a Cobb-Douglas social welfare function $\Omega=\alpha \log (U)+(1-\alpha) \log (S)$ with $\theta=1$. The demand for public employment is then unaffected by relative prices and productivities:

$$
L_{P}=\left(\frac{(1-\alpha)(1-T)(1-D)}{\alpha \eta}\right) \text {, so that } \hat{L}_{P}=-\hat{\eta}-\hat{T}-\delta D
$$


Demand for public services simply declines with the cost of public funds, the tax rate and the dependency ratio. However, even in this special case, the productivity in the market sector affects the demand for public employment through the cost of public funds. To see this, we loglinearise the cost of public funds defined in (13) whereby we recognise that the elasticity of labour supply $\varepsilon=(\sigma-1) V /(1-D)$ is variable:

(23) $\hat{\eta}=(\eta-1)\left(\widehat{\varepsilon}+\frac{1}{T} \widehat{T}\right)=(\eta-1)\left[\left(\frac{1}{T}+\varepsilon \frac{L}{V}\right) \hat{T}-\varepsilon \frac{L}{V} \AA_{M}\right]$ with $\eta-1=\left(\frac{\varepsilon\left(\frac{T}{1-T}\right)}{1-\varepsilon\left(\frac{T}{1-T}\right)}\right)$.

The cost of public funds exceeds one, especially if the tax rate is high and the elasticity of labour supply is large. If labour supply is inelastic $(\sigma=1)$ or becomes inelastic as people work so much that they run out of time ( $V$ close to zero), the cost of public funds drops to one. The two terms in the square brackets associated with $\varepsilon$ result from the endogenous nature of labour supply. They imply that a rise in the after-tax wage, induced by a cut in the tax rate or an increase in the productivity in the market sector, boosts labour supply and the tax base (if $\otimes 1$ ), and consequently lowers the cost of public funds. Note that the cost of funds does not depend on the dependency ratio $\delta$. The government budget constraint must now take account of the adverse effect of greying on labour supply (see equation (13)) and is thus given by:

$$
\mathrm{L}_{P}=\varepsilon \AA_{M}+\left(\frac{1-T}{\eta T}\right) \hat{T}-\delta \hat{D}
$$

\subsection{Equilibrium}

The demand curve (22), the cost curve (23) and the budget constraint $\left(10^{\prime}\right)$ can be solved simultaneously for the level of public services, the cost of public funds and the tax rate. To see this, we solve $(22)$ and $\left(10^{\prime}\right)$ for the demand for public revenue:

$$
\hat{T}=\frac{\left[(1-\theta)\left(\frac{L}{1-D}\right)-\varepsilon\right] A_{M}+\delta \hat{D}+(1-\theta)\left(v \hat{D}-\AA_{p}\right)-\theta \hat{\eta}}{\left(\frac{1-T}{\eta T}\right)+\theta+(1-\theta)\left(\frac{L}{1-D}\right)} .
$$

Substituting (23) into (24) and solving finally gives the optimal tax rate: 


$$
\hat{T}=\frac{\left[(1-\theta)\left(\frac{L}{1-D}\right)-\varepsilon+\theta(\eta-1) \varepsilon\left(\frac{L}{V}\right)\right] \AA_{M}+\delta \hat{D}+(1-\theta)\left(v \hat{D}-\AA_{P}\right)}{\left(\frac{1-T}{\eta T}\right)+\theta+(1-\theta)\left(\frac{L}{1-D}\right)+\theta(\eta-1)\left(\frac{1}{T}+\varepsilon \frac{L}{V}\right)} .
$$

Substitution of (25) into (23) and $\left(10^{\prime}\right)$ gives the changes in the cost of public funds and public employment. It is perhaps instructive to illustrate this solution diagrammatically. The demand curve (24) and the upward-sloping cost curve (23) are drawn in the right panel of Figure 1. The demand curve shows that the tax rate demanded for the finance of public services declines with the cost of public funds. The cost curve slopes upwards, since the marginal cost of public funds increases as the tax rate increases. The government budget constraint is given in the left panel of Figure 1. It indicates that a high tax rate allows more public employment.

Figure 1: Greying of population and better quality of public services

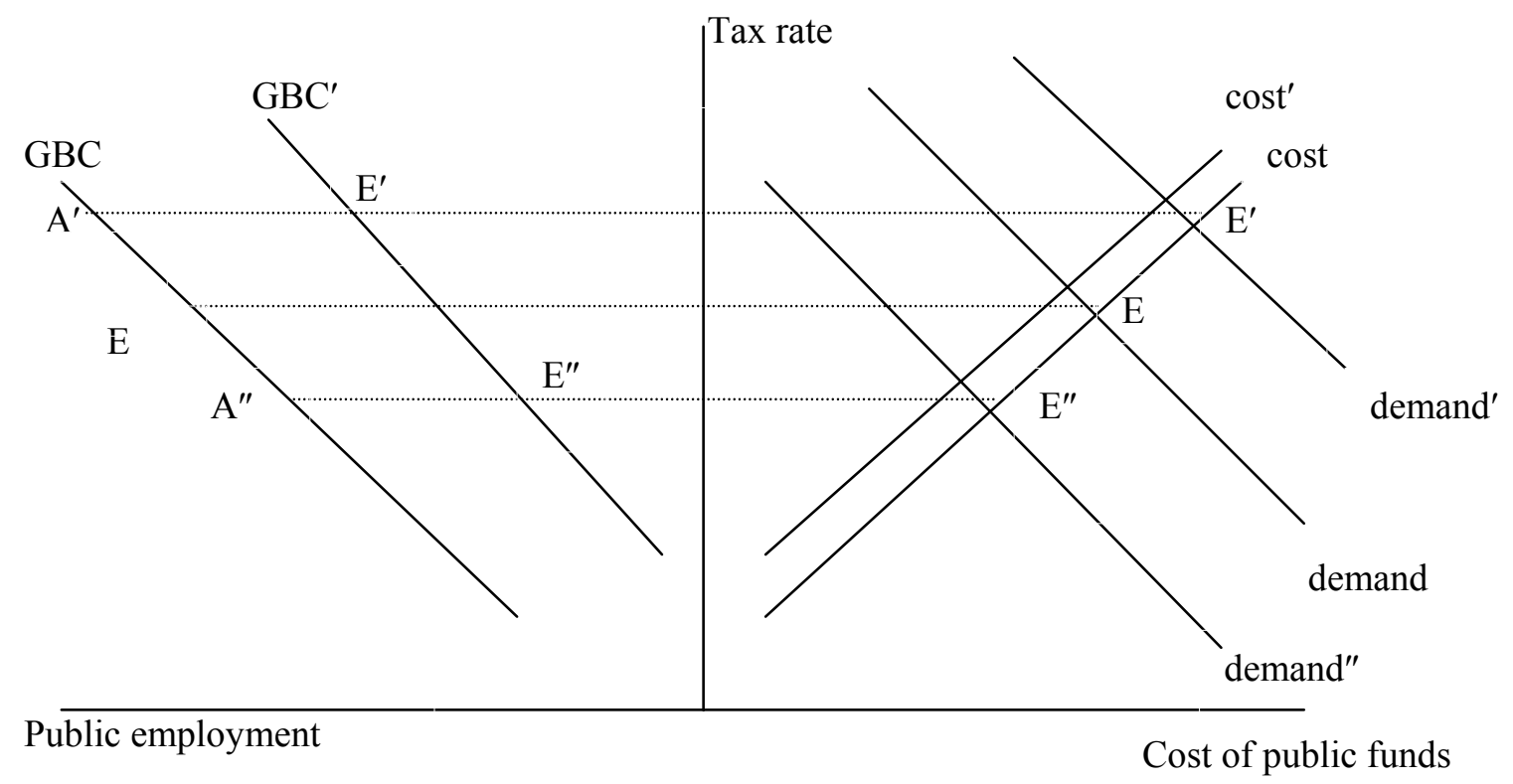

Key: Greying of the population shifts equilibrium from $\mathrm{E}$ to $\mathrm{E}^{\prime}$ if $\theta<1$ and to $\mathrm{E}^{\prime \prime}$ if $\theta>1$. Better quality of public services yields the same effects in the right-hand panel, but shifts the equilibrium in the left-hand panel to $\mathrm{A}^{\prime}$ if $\theta<1$ and to $\mathrm{A}^{\prime \prime}$ if $\theta>1$.

Greying of the population (rise in $D$ ) implies that less people work, so the tax base shrinks, the tax rate must rise and the government budget constraint $\left(10^{\prime}\right)$ shifts back and the demand curve for public services shifts up. Greying of the population does not affect the cost of funds schedule (23). The main effect of greying of the population is thus upward pressure on the tax 
rate and the cost of funds and a declining level of employment in public services. However, there is also a secondary effect of greying of the population. If public services are to some extent rival goods $(v>0)$ and poor substitutes for private goods $(\theta<1)$, greying of the population implies a further boost to the higher tax rate to finance a higher level of public services for a given cost of funds so that the demand curve (24) shifts out. Effectively, society demands more public services as it is difficult to substitute for material welfare. Greying of the population thus shifts the equilibrium from $\mathrm{E}$ to $\mathrm{E}^{\prime}$ and induces both a higher tax rate and a higher cost of public funds. This boosts employment in public services, but some or all of this may be offset by the shrinking of the tax base due to greying of the population. However, in the less likely case that public services are very good substitutes for private goods, the dependency ratio is small and rivalry in the provision of public services is substantial $(\theta>1+\delta / v)$, greying of the population shifts down the demand curve and moves the equilibrium from $\mathrm{E}$ to $\mathrm{E}^{\prime \prime}$. The result is a lower tax rate, a smaller cost of funds and unambiguously less employment in public services.

Better quality in the provision of public services goes together with more teachers in the class room and more nurses on the ward and thus with a fall in productivity in public services $\left(A_{P}\right.$ lower). The cost curve (16) and the government budget constraint (17) are unaffected. However, if private goods and public services are poor substitutes $(\theta<1)$, the demand for public services increases and thus the demand curve shifts out and the equilibrium moves from $\mathrm{E}$ to $\mathrm{A}^{\prime}$. Clearly, both the tax rate and the cost of public funds increase to make possible an increase of employment in public services. If private goods and public services are very good substitutes $(\theta>1)$, the equilibrium moves from $\mathrm{E}$ to $\mathrm{A}^{\prime \prime}$. The private component of utility increases and thus public employment falls. Consequently, the demand curve shifts back and both the tax rate and the cost of public funds fall.

Technical progress in the market sector boosts wages in the market sector and in public services. Figure 2 traces out the consequences for the tax rate, cost of funds and public sector employment. The tax base expands and thus, for a given tax rate, the government can afford more public services. The budget curve (17) thus shifts out. The cost of public funds must fall, since the higher wage boosts labour, reduces leisure and thus lowers the elasticity of labour supply. Consequently, the cost curve (16) shifts back. The demand curve (18) shifts out if private goods and public services are poor substitutes, the wage elasticity of labour supply is small and the ratio of active to inactive people is large, i.e., $(1-\theta) L /(1-D)>\varepsilon$.

Technical progress in the market sector thus shifts the equilibrium outcome from $\mathrm{E}$ to $\mathrm{E}^{\prime}$, so that the tax rate rises and demand for public sector employment expands. The cost of public funds increases (decreases) if the positive effect on the increases demand for public services on the cost of funds outweighs (is less than) the negative effect on leisure and the 
cost of funds. However, if labour supply is very elastic, greying of the population has lowered the number of active to inactive people and private goods and public services become better substitutes, rapid productivity improvements in the market economy will shift back the demand curve. In that case, the equilibrium may shift from $E$ to $E^{\prime \prime}$. Since the demand effect and the cost effect now reinforce each other, the net result is an unambiguous drop in the cost of public funds. The tax rate rises if the cost effect outweighs the demand effect. In that case, public sector employment expands. However, if the demand effect outweighs the cost effect, the tax rate falls and this tends to offset or even reverse the expansion of public services.

Figure 2: More rapid technological progress in the market economy

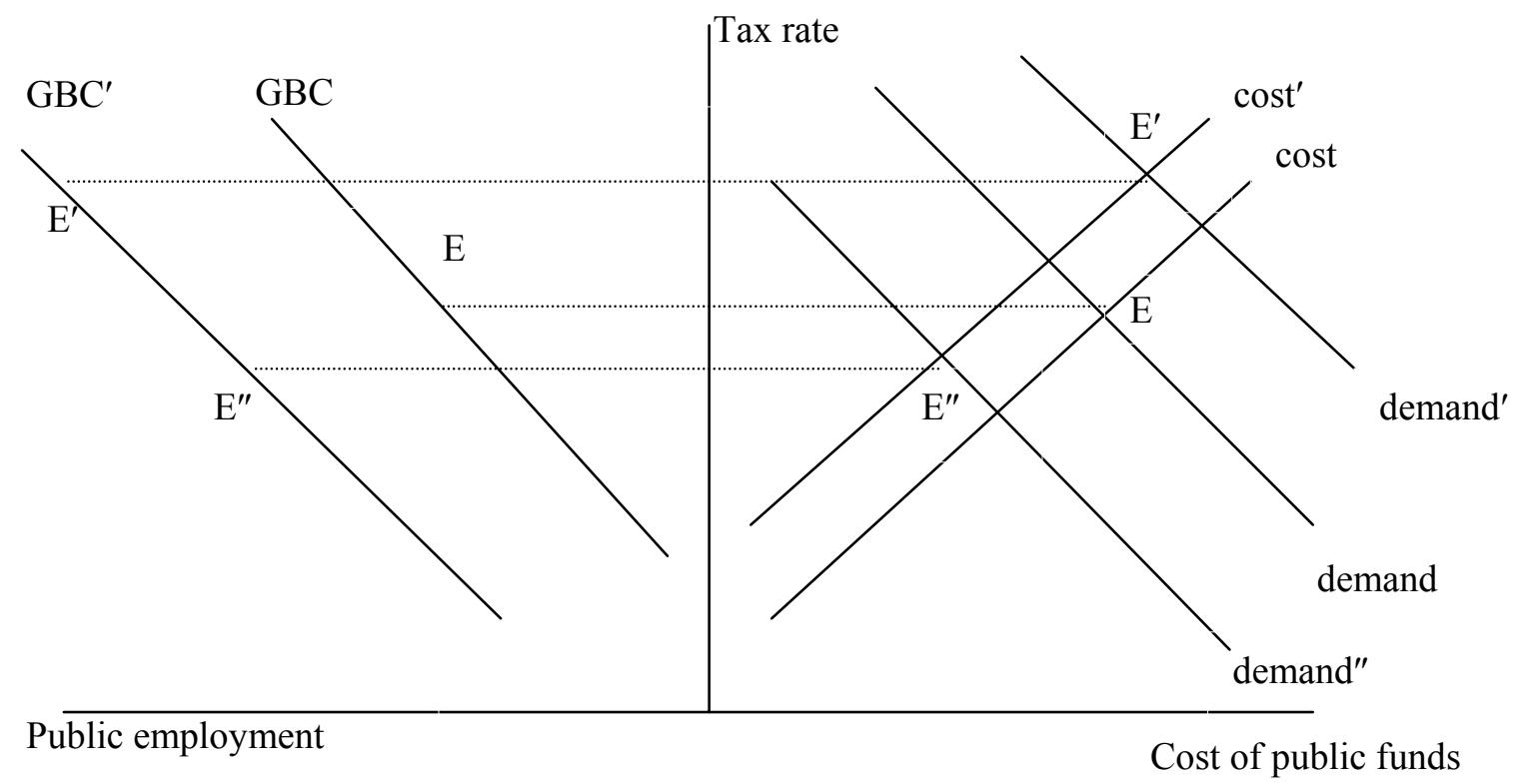

Key: Technical progress in the market economy shifts the equilibrium from $\mathrm{E}$ to $\mathrm{E}^{\prime}$ if $(1-\theta) L /(1-D)>\varepsilon$ and to $E^{\prime \prime}$ otherwise.

\section{Proposition 3:}

(A) If public services suffer from congestion effects and are poor substitutes for private goods, greying of the population boosts demand for public employment and thus pushes up the tax rate and the cost of public funds. The provision of public services per dependent may, however, fall due to the rise in the number of dependants and the consequent shrinking of the tax base. A better quality of public services also boosts the tax rate and public employment. However, if public services and private goods are very good substitutes, greying or a better quality of public services lowers the tax rate and always reduces the provision of public services. 
(B) Rapid technical progress in the market economy pushes up the tax rate and boosts public sector employment if private services and market goods are poor substitutes, the wage elasticity of labour supply is small and there are not too many pensioners and children. Public sector employment falls, however, if labour supply is very elastic, the number of pensioners and children is relatively large and the market provides good substitutes for public sector services.

There is a striking difference with Proposition 2, mainly because greying of the population now diminishes labour supply. Comparing equations (11) and (25), we see that greying now erodes the tax base and thus has an additional upward effect on the tax rate (indicated by the term $\delta \hat{D}$ in the numerator) and the cost of funds. The negative effect of greying on labour supply and public employment is now thus partially offset by an increase in the tax rate and the resulting increase in the demand for public employment. If substitution possibilities between public services and private welfare are small $(\psi<1$ or $\theta<1)$, equation (12) indicates that greying of the population always increases public employment provided that there are congestion effects in public services (i.e., $v>0$ ). Now Proposition 3 indicates that with adverse effects of greying on labour supply, the demand for public employment may well fall (especially if $\delta$ is large).

Proposition 3 also entails an important difference with Proposition 2 for the effect of more rapid technical progress in the market economy. The main reason is that this the ensuing growth in wages leads to less growth in labour supply as the wage elasticity of labour supply diminishes. As a result, the tax rate needs to rise more than in section 3. This is indicated by the third term in the square bracket in the numerator of expression (25) for the tax rate, since there is no equivalent of this term in expression (11).

\subsection{Some illustrative calculations}

To get an understanding of the order of magnitudes involved, we put some numbers to our results. Let us assume that the wage elasticity of labour supply equals 0.2 , the share of leisure taken by the workers is 0.4 , the elasticity of substitution between the provision of public services and private utility is 0.1 , the provision of public services is a rival good, zero technical progress in the stagnant sectors is zero, and the initial tax rate is 40 per cent. We then consider a doubling of the dependency ratio from 20 per cent in 2006 to 40 per cent in the next four decades. With an average rate of productivity growth in the market equal to 3 per cent per annum, productivity growth will increase by 226 per cent over the next forty years. We thus have the parameter values $\varepsilon=0.2, L /(L+V)=0.6, \theta=0.1$ and $v=1$ and the shocks 
$\hat{A}_{P}=0, \hat{A}_{M}=226 \%, \hat{\delta}=100 \%, \hat{D}=83.3 \%$. We start off with $\delta=0.2$ and $T=0.4$, which implies a cost of funds of $\eta=1.1538$. Expressions (25) and (10') then give:

$$
\begin{aligned}
& d T=0.1100 \hat{A}_{M}-0.2723 \hat{A}_{P}+0.3328 \hat{D}=(24.87+27.73) \% \text {-point }=52.6 \% \text {-point } \\
& \hat{L}_{P}=0.4374 \hat{A}_{M}-0.5877 \hat{A}_{P}+0.5183 \hat{D}=(98.86+43.19) \%=142.05 \% \text { and } \hat{S}=58.74 \% .
\end{aligned}
$$

Equations (13) and (14) give the corresponding effects on labour supply and private utility:

$$
\hat{L}=(28.5-16.2) \%=12.3 \% \text { and } \hat{U}=(110.7-61.1) \%=49.7 \%
$$

We thus see that the combination of a greying population and Baumol's cost disease (resulting from stagnant public services) more than double the tax rate. Labour supply increases due to the ongoing increase in the wage, even though it is offset to some extent by the hike in the tax rate. Greying of the population leads to shrinking of labour supply and thus to a smaller tax base and lower level of private utility, but the net effect on labour supply is positive. The net effect on private utility is also positive. Demand for public employment increases by $142 \%$ both due to the greater wealth arising from ongoing technical progress in the market economy and from the increasing number of pensioners. The provision of public services per dependent grows much less, since an ageing population makes it less easy to afford public services.

If there are more substitution possibilities between public services and market goods (e.g., $\theta=0.4$ ), the increases in the tax rate and public employment due to greying of the economy and Baumol's cost disease are less severe::

$$
\begin{aligned}
& d T=0.0481 \hat{A}_{M}-0.1613 \hat{A}_{P}+0.2150 \hat{D}=(10.87+17.92)-\text { point }=28.79 \% \text {-point, } \\
& \hat{L}_{P}=0.3038 \hat{A}_{M}-0.3481 \hat{A}_{P}+0.2640 \hat{D}=(68.66+22.00) \%=90.66 \%, \hat{S}=7.33 \%, \\
& \hat{L}=(35.6-16.2) \%=19.4 \% \text { and } \hat{U}=(146.5-67.9) \%=78.6 \% .
\end{aligned}
$$

We now see that the congestion of public services arising from an ageing population almost completely wipes out the increase in demand for public services arising from the higher wealth ensuing from ongoing technical progress in the market economy. Since market goods substitute for provision of public services, we see that the increase in labour supply and private utility are bigger than before.

These illustrative calculations suggest that both greying of the population and Baumol's cost disease boost the tax burden, but neither lead to public squalor nor threaten the welfare state. If public services manage to show some productivity growth the rise in the tax 
burden will be less severe while public employment need not rise as much. For example, if public services manage a productivity growth of one per cent per year, we have $\hat{A}_{p}=48.89 \%$. As a result, the tax rate will be 13.31 percentage-points if $\theta=0.1$ and 7.89 percentage-points lower if $\theta=0.4$. The growth of employment in public services will then only be $113.32 \%$ and $73.64 \%$, respectively.

If substitution between market goods and public services is easy enough, it is possible that the tax rate falls. For example, if $\theta=1$, productivity improvements in the public sector do not affect the tax rate or public employment. However, the combined effects of Baumol's cost disease and a greying population lead to a fall in the tax rate of -0.2 percentage points. Public employment increases then by $9.8 \%$ while the provision of public services falls by $73.6 \%$.

\section{5. 'If you pay peanuts, you get monkeys'}

The dislike of working in the public sector at the same wage as in the market sector is less if people value the good they do for others in society. We can allow for the immaterial value of working in public services by adding the term $\phi L_{P}$ to the private utility function. The wage in the public sector is now lower than in the market sector, since employees enjoy immaterial utility from working in the public sector. More precisely, $W_{P}=W_{M}-\phi /(1-T)<W_{M}$. Adding a gap between public and market sector pay reduces the costs of public employment, so the government needs to levy less taxes and can afford more public sector employment. As technical progress in the market economy advances, this effect vanishes. Since the joy from working in the public sector is untaxed, a higher tax rate resulting from greying of the population drives a bigger wedge between pay in the public and the market sector and makes it easier to afford public sector employment.

More interesting is perhaps to drop the assumption that private and public sector employment are perfect substitutes for households. They are not. Households have the option of working in the market sector at a wage $W_{M}=A_{M}$ or working in public services at a wage $W_{P}$. Extending the analysis of section 3 in this direction and dropping the assumption of a constant marginal utility of money, households maximise the following utility function:

$$
U=\log (C)-\left(\frac{\varepsilon}{1+\varepsilon}\right) L_{M}^{\frac{1+\varepsilon}{\varepsilon}}-\left(\frac{\varepsilon}{1+\varepsilon}\right) L_{P}^{\frac{1+\varepsilon}{\varepsilon}}, \text { where } \varepsilon \geq 0
$$

subject to the budget constraint $C=(1-T)\left(W_{M} L_{M}+W_{P} L_{P}\right)$. This yields the supply of labour to public services and to the market sector and the level of private consumption: 


$$
\begin{aligned}
& L_{P}=\left[1+\left(W_{P} / A_{M}\right)^{1+\varepsilon}\right]^{-\left(\frac{\varepsilon}{1+\varepsilon}\right)}, L_{P}=\left[1+\left(A_{M} / W_{P}\right)^{1+\varepsilon}\right]^{-\left(\frac{\varepsilon}{1+\varepsilon}\right)} \\
& \text { and } C=(1-T)\left[W_{P}^{1+\varepsilon}+A_{M}{ }^{1+\varepsilon}\right]^{\frac{1}{1+\varepsilon}}
\end{aligned}
$$

where labour in the market economy is paid its marginal productivity. Mobility of labour between the public and private sector is thus not perfect. We see that higher public sector pay, higher market sector pay and a lower tax rate boosts private consumption. Since the elasticity of substitution for private consumption is exactly unity, income and substitution effects cancel out exactly and thus the after-tax wage does not affect labour supply to the public sector and to the market. We thus focus on substitution from private to public jobs, which occurs if pay in the public sector rises relative to that in the market economy. Substitution of labour supplies into the government budget constraint $G=W_{P} L_{P}=T\left(W_{P} L_{P}+A_{M} L_{M}\right)$ yields:

$$
\frac{T}{1-T}=\left(\frac{W_{P}}{A_{M}}\right)^{1+\varepsilon} \quad \text { or } \quad L_{P}=T^{\frac{\varepsilon}{1+\varepsilon}}
$$

Hence, a higher tax rate makes it possible to afford a higher level of public employment and a higher ratio of public sector pay to the market wage. By making use of (22) and (23), we obtain an expression for indirect utility of households and for social welfare:

$$
\Omega=\left(\frac{\varepsilon}{1+\varepsilon}\right)[\log (1-T)-1]+\log \left(A_{M}\right)+V\left(\frac{A_{P} T^{\frac{\varepsilon}{1+\varepsilon}}}{D^{V}}\right)
$$

Maximising (24) with respect to the tax rate we obtain:

$$
C \mathrm{~V}^{\prime}(S)=P D^{v} \quad \text { or } \quad \mathrm{V}^{\prime}(S)=\left(\frac{D^{v}}{A_{P}}\right)\left(\frac{T^{\frac{1}{1+\varepsilon}}}{1-T}\right)
$$

Since income and substitution effects in labour supply cancel out, the cost of funds is unity. The only thing that changes is that the marginal utility of public services needs to be converted from utility units to resource units by dividing $\mathrm{V}^{\prime}(S)$ by the marginal utility of private consumption (i.e., 1/C). We see immediately see from the demand curve (25) and the cost curve (23) that, provided substitution possibilities between public services and market goods are small (i.e., $\psi<1$ ), a greying population or slower productivity growth in public 
services (perhaps to raise the quality of public services) pushes up the tax rate and the level of public employment. To make people move from private sector jobs to public sector jobs, the ratio of public sector pay to market wages must rise. Interestingly, ongoing rapid technical progress in the market economy does not affect the tax rate or the level of public employment. Neither does it affect public sector pay as a fraction of the market wage. Both public sector pay and the market wage increase at the same pace as productivity growth in the market economy. Prices of public services steadily increase at the excess of productivity growth in the market economy over that in the public sector. Of course, if we replace $\log (C)$ by $C^{1-1 / \varphi} /(1-1 / \varphi)$ in the household utility function, we find that after-tax wages have a positive impact on labour supplies if the substitution effect dominates the income effect (i.e., if $\varphi>1$. In that case, more rapid technical progress in the market economy boosts labour supply and thus expands the tax base. This makes possible gradual cuts in the tax rate and bigger provision of public services.

Another possible extension allows the government to encourage public employees to provide better public services. Well-known efficiency wage arguments suggest that higher public sector pay relative to the market wage makes it easier to recruit, retain and motivate those working in the public sector (cf., Summers, 1988; Layard, Nickell and Jackman, 1991). The government thus avoids the trap of 'if you pay peanuts, you get monkeys'. The government chooses both the wage in the public sector and the level of public employment to ensure a decent quality of public services. The government takes account of the higher tax rate that is needed to do this. If public sector pay lags behind the market wage, this cuts the public sector wage bill. However, this undermines public sector morale and public sector productivity. Public sector productivity is low and the extent of public sector employees being underpaid is large if labour supply is relatively inelastic and the tax rate on labour is low. In the limit as the tax rate goes to zero, the government cannot afford to pay any public sector wages whatsoever. A low wage elasticity of labour supply implies that the government is able to pay its employees less without risking them withdrawing their labour too much. More rapid ongoing technical progress in the market economy than in public services expands labour supply to the market more than that to the public sector, since the latter is more inelastic. Consequently, the government can afford to gradually push down the tax rate and increase the relative size of the market economy at the expense of the size of the public sector. The government reacts by trailing public sector pay behind productivity and pay in the market sector and as a result public sector morale and public sector productivity gradually fall. Since the tax rate gradually falls with time, it is clear that after-tax wages in the market sector increase by more than the 
rate of productivity growth in the market economy and thus labour supply to the market rises over time by more than it would otherwise.

\section{Concluding remarks}

If human services are provided by the market, more rapid technical progress in manufacturing than in services drives up the cost of human services. The rise in costs of human services is often perceived to be very rapid and terrifyingly persistent. Many worry that this will strain budgets of families, municipalities and central governments. Their main concern is that the inevitable rise in the cost of human services over and above the rate of inflation implies that the supply of these services will fall both in quantity and quality. However, there is no reason to worry about the decline of human services as the increased wealth of the nation permits a growing demand for human services. Each year less hours of work are therefore needed to purchase a given amount of human services. Education, care and other human services have in this sense become steadily cheaper, even though they appear to have become more unaffordable. In fact, if human services are luxury goods and poor substitutes for manufactured goods or if commercial human services substitute for household services within the household and thus release time for work and leisure, the budget share of human services in total income and employment in human services will inexorably rise over time. Even so, in a market economy where households voluntarily decide on consumption of human services and other goods, they happily spend a steadily increasing share of their budget on human services.

Problems may arise, however, if services such as education and health care are publicly provided and paid for by taxation. The big worry then is whether one can avoid a future of public squalor and private affluence. To investigate this properly, we must allow for the adverse incentive effects on labour supply. More rapid technical progress in the market economy drives up the relative cost of public services (Baumol's law). Also, growing incomes may boost demand for public services if they are luxury goods (Wagner's law). Greying of the population also increases the demand for public services, especially if they are rival public goods. Each of these three factors drives up the required tax revenue needed to finance public services. At the same time, as people become richer, they may choose to enjoy more leisure and work less. This together with the greying of the population narrows the tax base and necessitates a higher tax rate to finance the same level of public services. These two factors also reduce the viability of the welfare state. There are at least three offsetting factors. First, the increase in the cost of public services reduces the demand for public sector jobs. Second, growing incomes reduce the preference for work and thus increase the elasticity of labour supply. This raises the cost of public funds and thus depresses the demand for public 
sector jobs as well. Third, technical progress fuels the growth in wage and thus boosts the tax base. This brings in extra tax revenues.

The key question is thus whether these offsetting factors are strong enough to contain the aforementioned threats to the sustainability of the welfare state. We have demonstrated that, if the wage elasticity of labour supply and the initial tax rate are not too high, private goods and public services are poor substitutes and the number of dependants is not too large, relatively rapid progress in the market economy drives up the tax rate and the cost of public funds and thus permits a bigger level of employment in public services. As the market provides better substitutes for public services and greying boosts the number of dependants, technical progress can eventually reduce the provision of public services. We also showed that a better quality of provision of public services and, if public services are rival goods, greying of the population induce a bigger demand for public sector employment financed by a higher tax rate. Still, the provision of public services per dependent will fall as a result of a greying population.

If working in public services yields immaterial utility, public sector employees are paid below the market wage. Greying of the population drives up the tax rate and thus increases the wedge between pay in the public and market sector. This makes public sector employment more affordable. If public sector and market jobs are imperfect substitutes, greying of the population and a lower productivity growth of public services lead to a gradual increase in the tax rate, the ratio of public sector pay to the market wage and the level of public employment. If the substitution effects dominate income effects in labour supply, ongoing rapid technical progress in the market economy set of a process in the other direction. The increase in the tax base allows a gradual reduction in the tax rate and increase in the provision of public services despite the gradual increase in the relative price of public services. If the government realises that paying public sector workers below the market wage reduces productivity, the extent to which public sector employees are underpaid is greater as the tax rate is lower and the labour supply is less elastic. Relatively rapid technical progress in the market economy then induces a downward trend in the tax rate and a gradual expansion of the market economy and decline of public services. Public sector pay trails more and more behind market pay.

In future work, we wish to investigate the implications of household production of human services. Fast productivity growth in manufacturing leads to growing wage incomes and thus makes it more attractive to work in public services rather than provide household services oneself. This trend may be somewhat offset by a rising tax burden needed to finance the expansion of public services. We also intend to study the existence of both public services and market services. This requires a departure from the assumption of homogenous households in order to allow for income inequality. Public services are provided for all at the expense of the 
public purse, but may not offer as much choice or a high enough quality. Higher income groups may then prefer to opt out of public services and demand market services such as private schools or private health clinics. The key question is whether relatively rapid advances in technological progress in the manufacturing sector imply a gradual shift from public to market services as technical progress advances and incomes grow. An obvious advantage is that this may reduce the tax burden, but a disadvantage is that solidarity and equality of access to services may be undermined. Also, the quality of public services may gradually deteriorate as the best teachers, nurses and doctors move from the public to the private sector. Future work should also address the implications of Baumol's cost disease and a rising tax burden on saving and investment. Finally, we must investigate the possibility that public services display more rapid technical progress than manufacturing. This is relevant for the health cure where rapid innovation and invention of new techniques of medicine and medicines drive up health care costs (e.g., Jones, 2002). Especially if this type of curative care is financed by the public purse, there will be a strong demand for all these new possibilities for life extension to be covered by health insurance. Obviously, this drives up the tax burden and the cost of public funds, and stimulates calls for privatisation of curative care.

\section{References}

Andersen, T.(2006). The Scandinavian model - prospects and challenges, presented at the Netspar-CPB Conference 'Reinventing the Welfare State', The Social Economic Council (SER), The Hague, 27-28 April.

Baumol, W. (1967). Macroeconomics of unbalanced growth: The anatomy of urban crisis, American Economic Review, 57 (3), 415-426.

Baumol, W.J. (1973). Income and substitution effects in the Lindner theorem, Quarterly Journal of Economics, 87 (4), 629-633.

Baumol, W.J. (1996). Children of performing arts. The economic dilemma: the climbing costs of health care and education, Journal of Cultural Economics, 20 (3), 183-206.

Baumol, W., S. Blackman and E. Wolff (1985). Unbalanced growth revisited: Asymptotic stagnancy and new evidence, American Economic Review, 75, 806-817.

Cowen, T. (1996). Why I do not believe in the cost-disease. Comment on Baumol, Journal of Cultural Economics, 20, 207-214.

Jones, C.I. (2002). Why have health expenditures as a share of GDP risen so much?, Working Paper 9325, NBER, Cambridge, Mass.

Kuhry, B. and A. van der Torre (2002). De Vierde Sector. Achtergrondstudie Quartaire Sector, Sociaal en Cultureel Planbureau, Den Haag.

Layard, R., S. Nickell and R. Jackman (1991). Unemployment: Macroeconomic Performance and the Labour Market, Oxford University Press, Oxford. 
Lindbeck, A. (2005).Sustainable social spending, Working Paper No. 1594, CESifo, Munich.

Nordhaus, W.D. (2006). Baumol's diseases: a macroeconomic perspective, Working Paper 12218, NBER, Cambridge, Mass.

Ploeg, F. van der (2006). Growth, stagnation and structural change in the light of Baumol's cost disease, mimeo., European University Institute, Florence.

Summers, L.H. (1988). Relative wages, efficiency wages and unemployment, American Economic Review, Papers and Proceedings, 78, 383-388.

Triplett, J. and B. Bosworth (2003). Productivity measurement issues in service industries: "Baumol's disease" has been cured, Economic Policy Review, September, Federal Reserve Bank of New York. 


\section{CESifo Working Paper Series}

(for full list see www.cesifo-group.de)

1760 Pascalis Raimondos-Møller and Alan D. Woodland, Steepest Ascent Tariff Reforms, July 2006

1761 Ronald MacDonald and Cezary Wojcik, Catching-up, Inflation Differentials and Credit Booms in a Heterogeneous Monetary Union: Some Implications for EMU and new EU Member States, July 2006

1762 Robert Dur, Status-Seeking in Criminal Subcultures and the Double Dividend of ZeroTolerance, July 2006

1763 Christa Hainz, Business Groups in Emerging Markets - Financial Control and Sequential Investment, July 2006

1764 Didier Laussel and Raymond Riezman, Fixed Transport Costs and International Trade, July 2006

1765 Rafael Lalive, How do Extended Benefits Affect Unemployment Duration? A Regression Discontinuity Approach, July 2006

1766 Eric Hillebrand, Gunther Schnabl and Yasemin Ulu, Japanese Foreign Exchange Intervention and the Yen/Dollar Exchange Rate: A Simultaneous Equations Approach Using Realized Volatility, July 2006

1767 Carsten Hefeker, EMU Enlargement, Policy Uncertainty and Economic Reforms, July 2006

1768 Giovanni Facchini and Anna Maria Mayda, Individual Attitudes towards Immigrants: Welfare-State Determinants across Countries, July 2006

1769 Maarten Bosker and Harry Garretsen, Geography Rules Too! Economic Development and the Geography of Institutions, July 2006

1770 M. Hashem Pesaran and Allan Timmermann, Testing Dependence among Serially Correlated Multi-category Variables, July 2006

1771 Juergen von Hagen and Haiping Zhang, Financial Liberalization in a Small Open Economy, August 2006

1772 Alessandro Cigno, Is there a Social Security Tax Wedge?, August 2006

1773 Peter Egger, Simon Loretz, Michael Pfaffermayr and Hannes Winner, Corporate Taxation and Multinational Activity, August 2006

1774 Jeremy S.S. Edwards, Wolfgang Eggert and Alfons J. Weichenrieder, The Measurement of Firm Ownership and its Effect on Managerial Pay, August 2006 
1775 Scott Alan Carson and Thomas N. Maloney, Living Standards in Black and White: Evidence from the Heights of Ohio Prison Inmates, 1829 - 1913, August 2006

1776 Richard Schmidtke, Two-Sided Markets with Pecuniary and Participation Externalities, August 2006

1777 Ben J. Heijdra and Jenny E. Ligthart, The Transitional Dynamics of Fiscal Policy in Small Open Economies, August 2006

1778 Jay Pil Choi, How Reasonable is the 'Reasonable' Royalty Rate? Damage Rules and Probabilistic Intellectual Property Rights, August 2006

1779 Ludger Woessmann, Efficiency and Equity of European Education and Training Policies, August 2006

1780 Gregory Ponthiere, Growth, Longevity and Public Policy, August 2006

1781 Laszlo Goerke, Corporate and Personal Income Tax Declarations, August 2006

1782 Florian Englmaier, Pablo Guillén, Loreto Llorente, Sander Onderstal and Rupert Sausgruber, The Chopstick Auction: A Study of the Exposure Problem in Multi-Unit Auctions, August 2006

1783 Adam S. Posen and Daniel Popov Gould, Has EMU had any Impact on the Degree of Wage Restraint?, August 2006

1784 Paolo M. Panteghini, A Simple Explanation for the Unfavorable Tax Treatment of Investment Costs, August 2006

1785 Alan J. Auerbach, Why have Corporate Tax Revenues Declined? Another Look, August 2006

1786 Hideshi Itoh and Hodaka Morita, Formal Contracts, Relational Contracts, and the Holdup Problem, August 2006

1787 Rafael Lalive and Alejandra Cattaneo, Social Interactions and Schooling Decisions, August 2006

1788 George Kapetanios, M. Hashem Pesaran and Takashi Yamagata, Panels with Nonstationary Multifactor Error Structures, August 2006

1789 Torben M. Andersen, Increasing Longevity and Social Security Reforms, August 2006

1790 John Whalley, Recent Regional Agreements: Why so many, why so much Variance in Form, why Coming so fast, and where are they Headed?, August 2006

1791 Sebastian G. Kessing and Kai A. Konrad, Time Consistency and Bureaucratic Budget Competition, August 2006 
1792 Bertil Holmlund, Qian Liu and Oskar Nordström Skans, Mind the Gap? Estimating the Effects of Postponing Higher Education, August 2006

1793 Peter Birch Sørensen, Can Capital Income Taxes Survive? And Should They?, August 2006

1794 Michael Kosfeld, Akira Okada and Arno Riedl, Institution Formation in Public Goods Games, September 2006

1795 Marcel Gérard, Reforming the Taxation of Multijurisdictional Enterprises in Europe, a Tentative Appraisal, September 2006

1796 Louis Eeckhoudt, Béatrice Rey and Harris Schlesinger, A Good Sign for Multivariate Risk Taking, September 2006

1797 Dominique M. Gross and Nicolas Schmitt, Why do Low- and High-Skill Workers Migrate? Flow Evidence from France, September 2006

1798 Dan Bernhardt, Stefan Krasa and Mattias Polborn, Political Polarization and the Electoral Effects of Media Bias, September 2006

1799 Pierre Pestieau and Motohiro Sato, Estate Taxation with Both Accidental and Planned Bequests, September 2006

1800 Øystein Foros and Hans Jarle Kind, Do Slotting Allowances Harm Retail Competition?, September 2006

1801 Tobias Lindhe and Jan Södersten, The Equity Trap, the Cost of Capital and the Firm's Growth Path, September 2006

1802 Wolfgang Buchholz, Richard Cornes and Wolfgang Peters, Existence, Uniqueness and Some Comparative Statics for Ratio- and Lindahl Equilibria: New Wine in Old Bottles, September 2006

1803 Jan Schnellenbach, Lars P. Feld and Christoph Schaltegger, The Impact of Referendums on the Centralisation of Public Goods Provision: A Political Economy Approach, September 2006

1804 David-Jan Jansen and Jakob de Haan, Does ECB Communication Help in Predicting its Interest Rate Decisions?, September 2006

1805 Jerome L. Stein, United States Current Account Deficits: A Stochastic Optimal Control Analysis, September 2006

1806 Friedrich Schneider, Shadow Economies and Corruption all over the World: What do we really Know?, September 2006

1807 Joerg Lingens and Klaus Waelde, Pareto-Improving Unemployment Policies, September 2006 
1808 Axel Dreher, Jan-Egbert Sturm and James Raymond Vreeland, Does Membership on the UN Security Council Influence IMF Decisions? Evidence from Panel Data, September 2006

1809 Prabir De, Regional Trade in Northeast Asia: Why do Trade Costs Matter?, September 2006

1810 Antonis Adam and Thomas Moutos, A Politico-Economic Analysis of Minimum Wages and Wage Subsidies, September 2006

1811 Guglielmo Maria Caporale and Christoph Hanck, Cointegration Tests of PPP: Do they also Exhibit Erratic Behaviour?, September 2006

1812 Robert S. Chirinko and Hisham Foad, Noise vs. News in Equity Returns, September 2006

1813 Oliver Huelsewig, Eric Mayer and Timo Wollmershaeuser, Bank Behavior and the Cost Channel of Monetary Transmission, September 2006

1814 Michael S. Michael, Are Migration Policies that Induce Skilled (Unskilled) Migration Beneficial (Harmful) for the Host Country?, September 2006

1815 Eytan Sheshinski, Optimum Commodity Taxation in Pooling Equilibria, October 2006

1816 Gottfried Haber and Reinhard Neck, Sustainability of Austrian Public Debt: A Political Economy Perspective, October 2006

1817 Thiess Buettner, Michael Overesch, Ulrich Schreiber and Georg Wamser, The Impact of Thin-Capitalization Rules on Multinationals' Financing and Investment Decisions, October 2006

1818 Eric O’N. Fisher and Sharon L. May, Relativity in Trade Theory: Towards a Solution to the Mystery of Missing Trade, October 2006

1819 Junichi Minagawa and Thorsten Upmann, Labor Supply and the Demand for Child Care: An Intertemporal Approach, October 2006

1820 Jan K. Brueckner and Raquel Girvin, Airport Noise Regulation, Airline Service Quality, and Social Welfare, October 2006

1821 Sijbren Cnossen, Alcohol Taxation and Regulation in the European Union, October 2006

1822 Frederick van der Ploeg, Sustainable Social Spending in a Greying Economy with Stagnant Public Services: Baumol's Cost Disease Revisited, October 2006 